\title{
Analisis Faktor-Faktor Yang Mempengaruhi Partisipasi Masyarakat Dalam Pilkada Bali
}

\author{
${ }^{1}$ Ni Wayan Widhiasthini, ${ }^{2}$ Nyoman Sri Subawa, ${ }^{3}$ Nyoman Sedana, \\ ${ }^{4}$ Ni Putu Intan Permatasari \\ ${ }^{1234}$ Universitas Pendidikan Nasional Denpasar \\ e-mail:shribawa@undiknas.ac.id
}

Received: 13 April 2019; Revised: 30 April 2019; Accepted: 14 Mei 2019

\begin{abstract}
Community political participation is a political process in an effort to determine state decisions and policies to improve the welfare of the community. This research was conducted in the context of community participation, particularly Jembrana Regency which has a variety of different characteristics of the community. The problems formulated in this study are the factors that become obstacles to community participation in the regional elections of Bali Province. This study uses a quantitative approach with data analysis techniques, namely factor analysis, which aims to find factors that become a barrier for society to choose their governor. The respondents taken were 260 people with stratified proportional random ampling technique, from 5 sub-districts. Data collection techniques are carried out by doing observation, distributing questionnaires, and documentation. The results of the study concluded that the factors that inhibit volunteers in regional head elections are; 1) Not competent, 2) Geographical, 3) Not independent.
\end{abstract}

Keywords:, Community; Political; Voluntarism; Pilkada

\begin{abstract}
Abstrak
Partisipasi politik masyarakat merupakan proses politik dalam upaya menentukan keputusan dan kebijakan negara untuk menyejahterahkan masyarakatnya. Penelitian ini dilakukan dalam konteks partisipasi masyarakat, khususnya Kabupaten Jembrana yang memiliki ragam karakteristik masyarakat yang berbeda. Persoalan yang dirumuskan dalam penelitian ini adalah faktor yang menjadi penghambat partisipasi masyarakat pada pemilihan kepala daerah Provinsi Bali. Tujuan penelitian ini adalah untuk mencermati faktor penghambat partisipasi masyarakat pada pemilihan kepala daerah. Penelitian ini menggunakan pendekatan kuantitatif, dengan teknik analisis data yakni analisis faktor, yang bertujuan untuk mengkonfirmasi faktor penghambat masyarakat dalam memilih gubernur. Responden yang diambil sebanyak 260 responden dengan teknik stratified proportional random sampling, dan populasi sebanyak 225.725 dari 5 kecamatan. Teknik pengumpulan data dilakukan dengan melakukan observasi, menyebarkan kuesioner, dan dokumentasi. Hasil penelitian menyimpulkan bahwa faktor-faktor penghambat menjadi sukarelawan dalam pemilihan kepala daerah adalah; 1) Tidak memiliki kompetensi, 2) Geografis, 3) Tidak independen. Kontribusi penelitian adalah memberikan sumbangsih dalam kebijakan kepemiluan terutama dalam mengatasi rendahnya partisipasi masyarakat. Secara konseptual penelitian ini memberikan sumbangsih konsep tentang perubahan perilaku masyarakat dalam menggunakan hak pilihnya.
\end{abstract}

Kata Kunci: Masyarakat; Politik; Kesukarelaan; Pilkada

Link DOI : http://dx.doi.org/10.31314/pjia.8.1.1-11.2019 


\section{PENDAHULUAN}

Perencanaan dengan pendekatan partisipasitif merupakan sebagai strategi pembangunan dan proses penentuan keputusan publik, hal ini sangat bergantung pada kesadaran masyarakat untuk mau melibatkan diri dalam proses pembangunan (Akbar,MF,Suprapto,S \& Surati,2018).

Partisipasi politik masyarakat sangatlah penting dalam mewujudkan proses demokrasi yang ideal sehingga menciptakan pemerintahan yang baik dan bersih (good and clean governance). Partisipasi pemilih merupakan landasan dan praktek demokrasi yang menjadi tujuan tercapainya kesejahteraan masyarakat secara luas dan berkesinambungan. Namun demikian, partisipasi masyarakat menjadi permasalahan yang sangat prinsip dalam setiap momen pelaksanaan pemilihan kepala daerah. Demikian pula yang terjadi di Kabupaten Jembrana dalam Pilgub 2018. Masyarakat pemilih tidak menggunakan hak pilihnya disebabkan oleh beberapa alasan, diantaranya 1) Aspek geografis, Kabupaten Jembrana memiliki sebaran wilayah yang sangat luas dari segi kewilayahan, 2) Aspek kependudukan, dimana masyarakat yang tinggal di daerah pedesaan sangat sulit untuk menjangkau wilayah perkotaan sebagai pusat kota dan pemerintahan, 3) Aspek sosiologis, yang menunjukkan seringnya terjadi ketegangan dari tahap persiapan sampai ke tahap akhir pemilihan walaupun euphoria politik masyarakat Kabupaten Jembrana tidak terlalu tinggi. Fenomena ini terjadi di Kabupaten Jembrana yang menjadi lokus dalam penelitian ini dengan momen pemilihan kepala daerah Provinsi Bali (Pilgub 2018).

Terdapat beberapa penelitian yang menjadi referensi, Putra (2014) menyebutkan bahwa 63,89\% masyarakat Kelurahan Tuah Karya Kecamatan Tampan tidak memberikan partisipasi politiknya dalam Pemilihan tahun 2013. Hal ini menunjukkan bahwa tingkat partisipasi masyarakat sangat rendah, faktor penyebab masyarakat tidak memilih atau tidak menunjukkan partisipasi politik yang positif adalah; jauh dari Tempat Pemungutan Suara (TPS), lebih mementingkan kebutuhan ekonomi, sikap pesimisme terhadap kandidat yang maju pada Pilgub, sikap apatis terhadap Pilgub, dan lemahnya sosialisasi tentang kandidat yang mengikuti Pilgub.

Penelitian Nur, Taufik, Tahir (2015) tentang perilaku politik pemilih pemula dalam pemilihan presiden tahun 2014, menemukan bahwa faktor penghambat bagi pemilih pemula dalam menggunakan hak pilihnya adalah kepribadian aktor dan kurangnya sosialisasi. Kepribadian aktor yang dimaksud adalah kepribadian pemilih pemula itu sendiri dalam menunjukkan perilaku politiknya. Pemilih pemula lebih memikirkan pergaulan mereka dibanding mencari tahu tentang keadaan politik yang terjadi sekarang ini. Hasil penelitian

Mustadin (2013) menyebutkan bahwa terdapat empat faktor yang menjadi penentu terjadinya golput di Kota Yogyakarta, (1) faktor teknis yakni faktor pribadi pemilih misalnya pemilih sedang sakit, (2) faktor pekerjaan yakni pemilih tidak mendapatkan izin dari tempat mereka bekerja, (3) faktor administratif diantaranya, tidak terdata sebagai pemilih dan tidak mendapatkan kartu pemilihan, (4) faktor politik diantaranya, ketidakpercayaan masyarakat terhadap partai politik dan kandidat yang maju dalam pemilu. Penelitian ini menggunakan metode kualitatif dengan pendekatan teoritis dan melalui wawancara mendalam terhadap Komisi Pemilihan Umum di Kota 
Yogyakarta. Penelitian tersebut memberikan inspirasi terkait faktor apa yang menghambat masyarakat untuk berpartisiasi dalam pemilihan kepala daerah Provinsi Bali Tahun 2018 di Kabupaten Jembrana.

Lebih jauh, penelitan yang dilakukan Prasojo (2004) yang menyatakan warga negara yang sama sekali tidak melibatkan diri dalam partisipasi politik disebut apati (apaty), yang disebabkan oleh beberapa hal: pertama, adanya sikap acuh tak acuh, tidak tertarik atau rendahnya pemahaman mereka mengenai masalah politik. Kedua, adanya keyakinan bahwa usaha mereka untuk mempengaruhi kebijakan pemerintah tidak berhasil, ketiga, mereka tinggal dalam lingkungan yang menganggap bahwa tindakan apati merupakan suatu tindakan terpuji. Hasil penelitian Fenyapwain (2013) mengemukakan bahwa iklan politik dalam Pemilukada mempunyai pengaruh yang cukup kuat terhadap partisipasi pemilih pemula atau sekitar $17,30 \%$ sedangkan sisanya ditentukan oleh variabel lainnya, seperti faktor lingkungan, keluarga, nilainilai sosial yang dianutnya. Penelitian yang dilakukan Bawono (2008) tentang Perilaku Pemilih dalam menggunakan hak pilih menunjukkan bahwa sebagian pemilih yang tidak menggunakan hak pilih karena tidak diberi tahu dan tidak mau tahu, tidak terdaftar sebagai pemilih, bersikap pasif, tidak memahami manfaat Pemilu. Mereka memilih partai dan calon karena pertimbangan ikatan emosional pribadi, organisasi keagamaan, daerah asal calon, kultur atau budaya, dan lebih mempercayai keberadaan partai.

Penelitian yang dilakukan Wahyudi et al (2013) menunjukkan ada hubungan yang positif antara kepercayaan politik dan kepuasan demokrasi terhadap tingkat partisipasi politik mahasiswa. Semakin tinggi kepercayaan politik dan kepuasan demokrasi, maka semakin tinggi tingkat partisipasi politik mahasiswa, dimana partisipasi politik secara harfiah berarti keikutsertaan dalam konteks politik, keikutsertaan masyarakat dalam berbagai proses politik. Suharyanto (2014) dalam penelitiannya menyatakan masyarakat etnis Tionghoa di wilayah Kecamatan Semarang Tengah menjatuhkan pilihan politiknya didukung beberapa faktor, antara lain faktor lingkungan, selanjutnya faktor sosiologi yang ada pada masyarakat etnis tionghoa, berdasarkan informasi yang mereka terima melalui media/iklan politik serta pengetahuan yang diperoleh tentang profil partai, figur caleg serta visi dan misi kandidat ternyata berkorelasi dengan kondisi lingkungan dimana mereka tinggal, serta di dukung dengan faktor psikologis masyarakat etnis tionghoa sebagian menentukkan pilihan politiknya dengan memilih kandidat yang dilihat/dianggap mampu menampung dan memperjuangkan aspirasi mereka sebagai warga etnis Tionghoa.

Mereka yang aktif berpartisipasi dalam bidang politik adalah yang berpendidikan tinggi, status sosial ekonomi atas, tinggal di daerah perkotaan, berjenis kelamin laki-laki, pebisnis dan kaum kulit putih. sedangkan mereka yang partisipasi politiknya rendah adalah mereka yang berpendidikan rendah, status sosial ekonomi bawah, tinggal di pedesaan, berjenis kelamin perempuan, bekerja sebagai buruh kasar dan kaum kulit hitam.

Penelitian yang dilakukan Arwiyah (2012) mendukung hasil penelitian Haqqi, bahwa status sosial ekonomi berperan dalam meningkatkan partisipasi politik meskipun belum signifikan. Hal ini disebabkan masih terdapat pemilih yang berpendidikan tinggi, 
dan berpendapatan mapan kurang percaya terhadap partai politik. Pemilih yang memiliki pendidikan dan pendapatan rendah serta pekerjaan yang kurang mapan, lebih cenderung untuk memenuhi kebutuhan ekonomi terlebih dahulu daripada kehidupan politik. Hambatan geografis juga menjadi salah satu faktor yang mempengaruhi penyelenggaraan Pemilu, seperti hasil penelitian Payapo, et.al. (2014), bahwa faktor geografis mempengaruhi kualitas pemilukada, terbatasnya sarana dan prasarana (perkantoran dan transportasi), kurang tersedianya jaringan listrik dan internet, kurangnya jaringan komunikasi seperti yang terjadi pada Kabupaten Tambrauw, Maybrat, Teluk Bintuni, Raja Ampat, Wondama, dan Kaimana. Hal ini semakin dipertegas oleh Subawa \& Widhiasthini (2018), dalam penelitiannya bahwa peran media sosial dan teknologi informasi telah merubah perilaku masyarakat dalam menentukan pilihan dan mengambil keputusan atau tindakan. Dari uraian tersebut, dapat dikemukakan bahwa penelitian ini, membahas tentang fenomena sosial yang terjadi dan perubahan perilaku masyarakat dalam memilih. Beberapa faktor yang terdapat dalam hasil penelitian tersebut, kemudian menjadi rujukan dalam proses dan pembahasan dalam penelitian.

\section{METODE PENELITIAN}

Untuk menjawab rumusan masalah dalam penelitian ini, peneliti menggunakan pendekatan kuantitatif melalui analisis data yang digunakan adalah analisis faktor. Lokasi penelitian ini adalah Kabupaten Jembrana Provinsi Bali. Hal ini didasari atas beberapa alasan (1) wilayah geografis Jembrana cukup luas, bagi sebagian masyarakat cukup sulit untuk mengakses pusat Kota Jembrana, (2) partisipasi masyarakat dalam Pemilihan Serentak Tahun 2018 tergolong rendah yaitu 69,1\% (jika dibandingkan dengan target nasional 77,5\%), (3) karakteristik masyarakatnya yang heterogen, ditunjukkan oleh keberagaman sosial dan budaya, dan (4) Jembrana merupakan salah satu pintu gerbang dari Provinsi Bali. Untuk mengetahui jumlah variabel yang dapat diproses lebih lanjut maka ditampilkan tabel Anti Image Matrices.

Populasi dalam penelitian ini adalah masyarakat yang memiliki hak pilih dalam Pilgub Bali 2018 di Kabupaten Jembrana yang berjumlah 225.725 orang, yang memiliki peran sebagai volunteer (kesukarelaan) masyarakat, komunitas, dan kelompok lainnya dalam penyelenggaraan Pilgub Bali. Sampel yang diambil penelitian ini adalah 260 orang, didasarkan pada jumlah variabel yang diuji sebanyak 26 variabel, dan jumlah sampel adalah 5-10 kali jumlah variabel.Penentuan responden/sampel dilakukan dengan teknik stratified proporsional random sampling yang artinya peneliti menentukan sampel berdasarkan stratifikasi dan proporsi yang telah ditentukan berdasarkan pekerjaan, usia, status, pendidikan, wilayah (Kecamatan Jembrana, Melaya, Mendoyo, Negara dan Pekutatan). Stratifikasi tersebut digunakan sebagai kriteria untuk menetapkan sampel di masing-masing kelompok dan wilayah tempat tinggal kelompok, yang ditentukan secara acak.

\section{HASIL DAN PEMBAHASAN}

\section{Memilih variabel yang layak dimasukkan dalam analisis faktor}

Dari pengolahan data, dapat disajikan tabel 1 yang memuat Kaiser - Meyer - Olkin (KMO) and Bartlett's Measure of Sampling Adequacy (MSA).

\footnotetext{
4 Copyright $($ C 2019, Publik (Jurnal Ilmu Administrasi), Under the license CC BY-SA 4.0 ISSN: 2301-573X (Print), ISSN: 2581-2084 (Online)
} 


\begin{tabular}{clc}
\hline No & \multicolumn{1}{c}{ Variabel } & $\begin{array}{c}\text { Anti Image } \\
\text { Correlation }\end{array}$ \\
\hline 1 & Tidak adanya motivasi & 0,828 \\
2 & Tidak memiliki jaringan dalam kepemiluan & 0,837 \\
3 & Tidak paham alur kepemiluan & 0,736 \\
4 & Tidak memiliki kompetensi & 0,829 \\
5 & Tidak adanya kesempatan atau ruang dan waktu & 0,877 \\
6 & Tidak independen & 0,734 \\
7 & Tidak memiliki idealisme demokrasi & 0,744 \\
8 & Aktif sebagai anggota partai & 0,747 \\
9 & Tidak ada kesamaan persepsi dalam organisasi & 0,815 \\
& sukarelawan & \\
10 & Jarak tempat tinggal dan lokasi sukarelawan & 0,709 \\
11 & Telah memiliki pekerjaan tetap & 0,853 \\
\hline
\end{tabular}

Sumber : Olahan Data Primer

Pada tabel 1, dapat diketahui KaiserMeyer-Olkin and Bartlett's Measure of Sampling Adequacy (MSA) besarannya adalah 0,800 dan nilai signifikansi $=0,000$. Oleh karena nilai KMO hasil pengolahan data lebih besar dari 0,5 dan nilai signifikansi lebih kecil dari 0,05 maka kumpulan variabel tersebut dapat diproses lebih lanjut.

Selanjutnya dilakukan analisis faktor dengan Anti Image Matrices yang digunakan untuk menentukan variabel yang dapat dianalisis lebih lanjut dan variabel yang harus dikeluarkan. Kriteria penentuan Anti Image Matrics adalah angka korelasi yang terdapat pada Anti Image Correlation (angka korelasi yang berisi tanda "a", yaitu angka yang terletak pada arah diagonal dari kiri atas ke kanan bawah). Bila angka korelasi yang diperoleh sebuah variabel lebih besar dari 0,5 maka variabel tersebut dapat dianalisis. 
Berdasarkan data pada tabel 2 dapat diketahui Anti Image Correlation kesebelas variabel yang diuji adalah lebih besar dari 0,50. Artinya bahwa kesebelas variabel memiliki nilai Anti Image Correlation lebih besar dari 0,5 yang berarti telah memenuhi syarat untuk diproses lebih lanjut.

\section{Ekstraksi variabel}

Seluruh variabel yang diuji memiliki nilai Anti Image Correlation lebih besar dari 0,5 dan seluruh variabel tersebut tidak ada yang dikeluarkan dari analisis. Artinya seluruh variabel memenuhi syarat untuk diproses lebih lanjut. Proses selanjutnya berupa proses faktoring dan ekstraksi, yang ditampilkan pada tabel 3. Data extraction pada tabel communalities tersebut, menunjukkan deskripsi besaran sebuah variabel, yang dapat dijelaskan oleh faktor yang terbentuk. Dapat dijelaskan bahwa variabel tidak adanya motivasi, angka extraction adalah 0,612. Hal ini berarti sekitar $61,2 \%$ varians dari variabel tidak adanya motivasi dapat dijelaskan oleh faktor yang nanti terbentuk. Demikian juga, terhadap variabel, yakni tidak memiliki jaringan dalam kepemiluan, angka extraction adalah 0,638. Hal ini berarti sekitar $63,8 \%$ varians dari variabel tidak memiliki jaringan dalam kepemiluan dapat dijelaskan oleh faktor yang akan terbentuk. Untuk menentukan jumlah faktor yang terbentuk, dapat dilihat dari Initial Eigenvalue. Hal ini dapat dilihat pada tabel 3. Dari data pada tabel tersebut, terbentuk tiga faktor yang memiliki nilai Initial Eigenvalue lebih besar dari 1, yaitu faktor pertama memiliki Initial Eigenvalue $=4,370$ dan faktor kedua $=1,497$ serta faktor ketiga $=1,211$. Sedangkan 9 faktor lainnya memiliki nilai Initial Eigenvalue lebih kecil dari 1. Faktor yang memiliki nilai Initial Eigenvalue lebih kecil dari 1 tidak digunakan dalam menghitung jumlah faktor. Ini berarti jumlah faktor yang terbentuk hanyalah 3 (tiga). Proses penetapan variabel yang akan masuk ke dalam suatu faktor dilakukan dengan membandingkan besarnya koefisien korelasi pada setiap baris. Interpretasi dilakukan dengan melihat faktor loading (korelasi) status variabel dengan faktornya. Batasan faktor loading minimal 0,5. Bila faktor loading sebuah variabel lebih kecil dari 0,5 maka variabel tersebut dikeluarkan dari model.

Selanjutnya mengacu pada tabel 4 component matric, dapat dijelaskan korelasi sebagai berikut.

a. Korelasi antara variabel tidak memiliki kompetensi dengan faktor 1 adalah 0,794. Artinya memiliki korelasi sangat kuat.

b. Korelasi antara variabel tidak memiliki kompetensi dengan faktor 2 adalah 0,149 . Artinya bahwa memiliki korelasi negatif yang lemah.

c. Korelasi antara variabel tidak memiliki kompetensi dengan faktor 3 adalah 0,164 . Nilai tersebut menunjukkan korelasi yang lemah

Koefisien korelasi (faktor loading) pada variabel tidak memiliki kompetensi, memiliki nilai terbesar, dan berada pada faktor 1, maka variabel tersebut bisa dimasukkan sebagai komponen faktor. Pada beberapa variabel terdapat faktor loading yang hampir sama besarnya sehingga hal ini menyulitkan untuk memasukan dalam faktor 1, 2 dan 3. Oleh sebab itu akan dilakukan rotasi kembali, agar lebih jelas faktor loading-nya. 


\section{Tabel 3. Total Variance Explained}

\begin{tabular}{|c|c|c|c|c|c|c|}
\hline \multirow{2}{*}{ Component } & \multicolumn{3}{|c|}{ Initial Eigenvalues } & \multicolumn{3}{|c|}{$\begin{array}{c}\text { Extraction Sums of Squared } \\
\text { Loadings }\end{array}$} \\
\hline & Total & $\begin{array}{c}\% \text { of } \\
\text { Variance }\end{array}$ & $\begin{array}{c}\text { Cumulative } \\
\%\end{array}$ & Total & $\begin{array}{c}\% \text { of } \\
\text { Variance }\end{array}$ & $\begin{array}{c}\text { Cumulative } \\
\%\end{array}$ \\
\hline 1 & 4.370 & 39.732 & 39.732 & 4.370 & 39.732 & 39.732 \\
\hline 2 & 1.497 & 13.608 & 53.340 & 1.497 & 13.608 & 53.340 \\
\hline 3 & 1.211 & 11.006 & 64.346 & 1.211 & 11.006 & 64.346 \\
\hline 4 & .781 & 7.097 & 71.443 & & & \\
\hline 5 & .688 & 6.257 & 77.700 & & & \\
\hline 6 & .577 & 5.243 & 82.943 & & & \\
\hline 7 & .487 & 4.429 & 87.372 & & & \\
\hline 8 & .407 & 3.701 & 91.073 & & & \\
\hline 9 & .406 & 3.687 & 94.761 & & & \\
\hline 10 & .334 & 3.038 & 97.799 & & & \\
\hline 11 & .242 & 2.201 & 100.000 & & & \\
\hline
\end{tabular}

Sumber : Olahan Data Primer

Tabel 4 Component Matrik ${ }^{a}$

\begin{tabular}{lrrr}
\hline & \multicolumn{3}{c}{ Component } \\
& 1 & 2 & \multicolumn{1}{c}{3} \\
\hline Tidak memiliki kompetensi (x4) & .794 & -.149 & .164 \\
Tidak ada kesamaan persepsi dalam organisasi sukarelawan (x9) & .725 & .265 & -.147 \\
Tidak adanya kesempatan atau ruang dan waktu (x5) & .697 & -.228 & -.298 \\
Tidak adanya motivasi (x1) & .679 & -.288 & .260 \\
Tidak memiliki jaringan dalam kepemiluan (x2) & .675 & -.389 & .178 \\
Telah memiliki pekerjaan tetap (x11) & .659 & -.035 & -.492 \\
Tidak memiliki idealisme demokrasi (x7) & .554 & .286 & .430 \\
Aktif sebagai anggota partai (x8) & .551 & .598 & .193 \\
Tidak paham alur kepemiluan (x3) & .400 & -.590 & .334 \\
Tidak independen (x6) & .513 & .573 & .175 \\
Jarak tempat tinggal dan lokasi sukarelawan (x10) & .587 & .032 & -.606 \\
\hline
\end{tabular}

\section{Sumber : Olahan Data Primer}

Dari hasil proses rotasi yang dilakukan terlihat lebih jelas dan nyata faktor loading untuk setiap variabel. Bila faktor loading sebelumnya kecil, maka akan menjadi lebih kecil. Jika faktor loading sebelumnya besar, maka akan menjadi lebih besar. Component Matrix hasil proses rotasi. Memperhatikan tabel 5, diketahui bahwa 11 variabel penelitian tersebut, telah terbentuk 3 faktor sebagai berikut. 
Tabel 5 Rotated Component Matrik ${ }^{\mathrm{a}}$

\begin{tabular}{llrl}
\hline & \multicolumn{3}{c}{ Component } \\
& 1 & 2 & \multicolumn{1}{l}{3} \\
\hline Tidak paham alur kepemiluan (x3) & .780 & -.011 & -.102 \\
Tidak memiliki jaringan dalam kepemiluan (x2) & .738 & .274 & .136 \\
Tidak adanya motivasi (x1) & .712 & .210 & .246 \\
Tidak memiliki kompetensi (x4) & .643 & .352 & .375 \\
Jarak tempat tinggal dan lokasi sukarelawan (x10) & .043 & .837 & .106 \\
Telah memiliki pekerjaan tetap (x11) & .183 & .791 & .137 \\
Tidak adanya kesempatan atau ruang dan waktu (x5) & .423 & .664 & .087 \\
Tidak ada kesamaan persepsi dalam organisasi & & & \\
sukarelawan (x9) & .185 & .549 & .531 \\
Aktif sebagai anggota partai (x8) & & & \\
Tidak independen (x6) & .023 & .166 & .819 \\
Tidak memiliki idealisme demokrasi (x7) & .008 & .157 & .773 \\
\hline
\end{tabular}

Sumber : Olahan Data Primer

1. Faktor 1 yang meliputi, tidak paham alur kepemiluan, tidak memiliki jaringan dalam kepemiluan, tidak adanya motivasi dan tidak memiliki kompetensi. Kemudian dari faktor 1 ini dan variabel yang membentuknya maka dapat dilakukan pemberian nama pada faktor 1 adalah tidak paham alur, tidak memiliki jaringan dan tidak berkompetensi.

2. Faktor 2 terdiri atas, jarak tempat tinggal dan lokasi sukarelawan, telah memiliki pekerjaan tetap, tidak adanya kesempatan atau ruang dan waktu dan tidak ada kesamaan persepsi dalam organisasi sukarelawan.
3. Faktor 3 terdiri atas, variabel aktif sebagai anggota partai, tidak independen dan tidak memiliki idealisme demokrasi.

Hasil proses rotasi matrik, dapat dianalisis bahwa variabel-variabel yang diuji dalam penelitian ini, menunjukkan kejelasan variabel berada pada faktor yang mana dari 3 faktor yang terbentuk. Setiap variabel telah memiliki koefisien korelasi (loading faktor) yang kuat dengan salah satu faktor yang terbentuk.

\section{Penamaan faktor}

Faktor yang merupakan gabungan lebih dari satu variabel perlu diberi nama. Pemberian nama memakai pendekatan surrogate variable, yang artinya mencari 
dan menemukan salah satu variabel dari setiap faktor yang merupakan representasi dari variabel-variabel tersebut dan pemilihan nama dapat ditentukan pada faktor loading tertinggi dan atau nama lain (baru) yang mewakili dan menunjukkan karakteristik perwakilan terhadap kumpulan variabelvariabel tersebut. Penamaan terhadap faktorfaktor yang terbentuk adalah sebagai berikut.

a. Faktor 1 terdiri atas, tidak paham alur kepemiluan, tidak memiliki jaringan dalam kepemiluan, tidak adanya motivasi dan tidak memiliki kompetensi. Untuk selanjutnya faktor ini disebut dengan nama "Faktor Tidak Memiliki Kompetensi”. Kompetensi didefinisikan sebagai pengetahuan, ketrampilan dan sikap yang dimiliki seseorang dalam bidang tertentu, dan terlihat pada konteks pekerjaan. Kompetensi ditunjukkan dalam kerja dan perilaku tempat kerja.

b. Faktor 2 terdiri atas, jarak tempat tinggal dan lokasi sukarelawan, telah memiliki pekerjaan tetap, tidak adanya kesempatan atau ruang dan waktu dan tidak ada kesamaan persepsi dalam organisasi sukarelawan. Untuk selanjutnya faktor ini disebut dengan nama "Faktor Geografis". Geografis menunjukkan letak suatu wilayah/daerah, secara nyata posisi daerah tersebut.

c. Faktor 3 terdiri atas, aktif sebagai anggota partai, tidak independen dan tidak memiliki idealisme demokrasi. Untuk selanjutnya faktor ini disebut dengan nama "Faktor Tidak
Independen". Independen dimaknai sebagai bebas, berdiri sendiri dan merdeka. Jadi, tidak Independen berarti tidak berafiliasi dengan partai politik manapun, berpihak kepada atau mendukung partai politik tertentu.

Dari uraian di atas, dapat dijelaskan bahwa dari 11 indikator yang mempengaruhi penghambat menjadi sukarelawan Pilgub 27 Juni 2018 di Kabupaten Jembrana dapat direduksi menjadi 3 faktor saja. Dari ketiga faktor tersebut dapat diketahui bahwa faktor 1 dengan nama "Faktor Tidak Memiliki Kompetensi" mempunyai pengaruh paling dominan karena memiliki Initial Eigenvalue paling besar, yaitu 4,370. Selanjutnya, faktor 2 dengan nama "Faktor Geografis" memiliki Initial Eigenvalue sebesar 1,497. Terakhir, faktor 3 dengan nama "Faktor Tidak Independen" memiliki Initial Eigenvalue sebesar 1,211.

Dalam penelitian Parawansa (2002) menunjukkan bahwa faktor ijin pasangan menjadi penghambat dalam berproses dan partisipasi dalam politik, khususnya para wanita. Artinya, keikutsertaan secara aktif dalam berpolitik melalui media-media yang ada pada era saat ini, forum, jejaring sosial, dan diskusi-diskusi terbatas (Mudjiyanto, 2012). Sesungguhnya, peran aktif semua komponen masyarakat dalam ikut serta berpartisipasi politik sangat diharapkan. Seperti diuraikan oleh Kusmanto (2013) dalam penelitiannya, bahwa komponen masyarakat melalui peran Badan Permusyawaratan Desa dalam sosialisasi partisipasi politik masyarakat dalam bentuk diskusi, penyuluhan dan pendidikan politik 
Available Online at http://journal.umgo.ac.id/index.php/Publik

Publik (Jurnal Ilmu Administrasi) Vol 8 (1), Juni 2019

masyarakat. Miharjo (2014) mengemukakan dan dapat diintepretasikan bahwa dengan pendidikan politik yang baik dan memahami karakteristik masyarakatnya akan dapat mengurangi persoalan-persoalan dan mengelola konflik sosial di masyarakat. Kompetensi masyarakat perlu ditingkatkan dalam pemahaman pendidikan politik dan dampak yang dapat timbul akibat perbedaan pandangan dan pendapat.

\section{PENUTUP}

\section{Kesimpulan}

Berdasarkan pembahasan dapat dirangkum dan disimpulkan bahwa faktor penghambat menjadi sukarelawan Pemilihan Gubernur dan Wakil Gubernur (Pilgub) 2018, adalah 1) Faktor Tidak Memiliki Kompetensi, 2) Faktor Geografis; 3) Faktor Tidak Independen, dimana masing-masing faktor merupakan hasil reduksi dari berbagai faktor. Penelitian ini dapat memberikan rekomendasi untuk menjadi kajian pada penelitian-penelitian selanjutnya, seperti: budaya follower yang ditimbulkan dari maraknya iklan kampanye di media sosial, hambatan bagi perempuan dalam menggunakan hak politiknya mengingat jumlah penduduk perempuan lebih banyak dari laki-laki.

\section{Saran}

Saran yang dapat diberikan dari penelitian ini adalah penerapan kebijakan yang tepat dalam upaya meningkatkan partisipasi dan kesukarelaan masyarakat dalam menggunakan hak politiknya dengan memperhatikan kearifan lokal.

\section{DAFTAR PUSTAKA}

Akbar, MF, Suprapto, S., \& Surati, S. (2018). Partisipasi Masyarakat Dalam Perencanaan Pembangunan di Desa Jatimulya Kabupaten Boalemo. Publik (Jurnal Ilmu Administrasi), 6(2), 135-142. doi:http://dx.doi.org/10.31314/pjia.6. 2.135-142.2017

Arwiyah, M. Y. (2012). Status Sosial Ekonomi dan Kualitas Partai Politik. XXVIII (1), 85-92.

Bawono, Muhammad (2008) Persepsi dan Perilaku Pemilih terhadap Partisipasi Politik dalam Pemilihan Umum Legislatif 2004 di Kabupaten Nganjuk. Universitas Sebelas Maret. Tersedia di:https://eprints.uns.ac.id/5 $\underline{429 /}$

Fenyapwain, M.M. (2013) Pengaruh Iklan Politik dalam Pemilukada Minahasa terhadap Partisipasi Pemilih Pemula di Desa Tounelet Kecamatan Kakas. Jurnal ACTA DIURNA. Vol 2, No 1 tersedia di: https://ejournal.unsrat.ac. id/index.php/actadiurna/article/view/ $\underline{975}$

Kusmanto, Heri. (2013) Peran Badan Permusyawaratan Daerah dalam Meningkatkan Partisipasi Politik Masyarakat. Jurnal Ilmu Pemerintahan dan Sosial Politik UMA. Vol 1, No 1. tersedia di: http://ojs.uma.ac.id/index.php/jppum a/article/view/550

Miharjo, S (2014) Pengaruh Faktor Kompetensi terhadap Strategi Pencegahan Konflik Sosial di Kota Ternate. Repository Universitas 


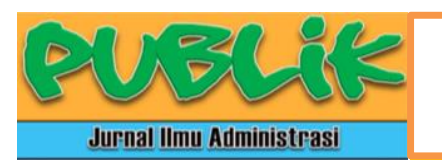

Terbuka.

Mudjiyanto, Bambang (2012) Literasi Internet dan Partisipasi Politik Masyarakat Pemilih dalam Aktifitas Pemanfaatan Media Baru (Survey Masyarakat Pemilih Pilkada, Kasus Masyarakat Bengkulu) Jurnal Studi Komunikasi dan Media.Vol. 16 (1)

Mustadin. (2013). Analisis Potensi Golput pada Pemilu 2014 di Kota Yogyakarta. Jurnal Psikologi Integratif, 1(1), pp.175-186

Nur, R., Taufik, A., Tahir, M. (2015). Perilaku Politik Pemilih Pemula dalam Pelaksanaan Pemilihan Presiden 2014 di Desa Kanaungan Kecamatan Labakkang Kabupaten Pangkep. Jurnal Ilmu Pemerintahan, 5(1), pp.91-106

Parawansa, K.I. (2002). Perempuan di Parlamen. Bukan Sekedar Jumlah, Hambatan terhadap Partisipasi Politik Perempuan di Indonesia. Academia.Edu

Payapo, RMT. Ruslan, A. Halim, H. (2014) Penguatan Kelembagaan Komisi Pemilihan Umum Provinsi Papua Barat dalam Meningkatkan Kualitas Pelaksanaan Pemilihan Umum Kepala Daerah. Analisis. Vol. 3 No 1. $90-100$

Putra, R.D. (2014). Faktor yang Menyebabkan Masyarakat Tidak Menggunakan Hak Pilihnya dalam Pemilihan Gubernur dan Wakil Gubernur Tahun 2013 di TPS 5 RT 4 RW 1 Kelurahan Tuah Karya Kecamatan Tampan. Jurnal Sosiologi Fakultas Ilmu Sosial dan
Ilmu Politik Universitas Riau, 1(2), pp.1-15

Prasojo, E. (2004) People and Society Empowerment: Perspektif Membangun Partisipasi Publik. Jurnal Ilmiah Administrasi Publik. academia.edu.

Subawa, N. S., \& Widhiasthini, N. W. (2018). Transformasi Perilaku Konsumen Era Revolusi, Prosiding. Conference On Management And Behavioral Studies. ISSN 25413406; e-ISSN 2541-285X. p. 131139.

Suharyanto, Agung. (2014) Partisipasi Politik Masyarakat Tionghoa dalam Pemilihan Kepala Daerah. Jurnal Ilmu Pemerintahan dan Sosial Politik UMA. (2) 151-160 tersedia di: http://www.ojs.uma.ac.id/index.p hp/jppuma/article/view/920

Wahyudi, H., Fernando, T., Ahmad, A., Khairani, A., Agung, I. M., \& Milla, M. N. (2013). Peran Kepercayaan politik dan Kepuasan Demokrasi terhadap Partisipasi Politik Mahasiswa. 